\title{
NEW CHARTS FOR PATIENTS TREATED BY INTERMITTENT POSITIVE PRESSURE VENTILATION
}

\author{
Major C. K. DAVIES \\ M.A., B.M., B.Ch., F.F.A.R.C.S., D.T.M.\&H., R.A.M.C. \\ Major R. St. J. ANGEL \\ M.B., B.S., F.F.A.R.C.S., D.Obst.R.C.O.G., R.A.M.C. \\ Cambridge Military Hospital, Aldershot, Hampshire
}

DESPITE the decreased incidence of paralytic poliomyelitis, intermittent positive pressure ventilation is being used more and more in Military Hospitals. Chest injuries, tetanus, head injuries, encephalitis and a variety of other conditions may require this method of treatment. However, the technique is highly sophisticated, and scrupulous attention to detail is necessary if management is to be successful and complications are to be avoided.

One essential to good management is careful documentation, and Spalding and Crampton Smith (1963) have described a Chart and a Treatment Sheet used in the Respiration Unit at the United Oxford Hospitals. These are shown in Figures 1 \& 2 respectively. On the Treatment Sheet, the doctor in charge of the case writes his daily instructions for the frequency of the various procedures, and in the case of items such as minute volume, the values to be maintained. Observations ordered on the Treatment Sheet are recorded on the Chart, which is self-explanatory. Apart from these special forms, conventional fluid and temperature charts are required to complete documentation.

The Army Medical Services have no such forms of their own, so that treatment instructions are generally written in the case notes, or on loose pieces of paper, while charting is carried out on the ordinary temperature chart (F. Med 13). This is not a very satisfactory arrangement, and at British Military Hospital, Singapore, typewritten stencils of the Oxford Chart and Treatment Sheet have been prepared, and the duplicated proformata so produced have been in successful use for some time.

The authors intended to make similar stencils to use in the Cambridge Military Hospital, but decided that modification of the forms would be more useful in the special circumstances of military medicine. Compared with the Respiration Unit for which the Oxford forms were designed, Military Hospitals see very few of these cases. Consequently the medical and nursing staff may have had no recent experience of the technique, and this is particularly likely in the more remote overseas stations. For example, one of us treated only one patient with intermittent positive pressure ventilation in two years in Malaya. It is essential, despite this, that a meticulous regime should be established early, before evacuation or the arrival of more experienced help.

The Treatment Sheet has therefore been modified to include a column detailing the usual intervals at which procedures should be carried out, and giving a few reminders on technique. A further modification is the incorporation of columns in which the procedures may be ticked off as they are performed, making supervision easier. The Sheet thus becomes, not merely a list of instructions, but also an aide-memoire and a record of treatment given, Described now as "Artificial Ventilation Instruction and Record Sheet", it is illustrated in Figure 3. Diet and biochemistry have been omitted largely through considerations of space, as it was thought desirable to limit the size of 


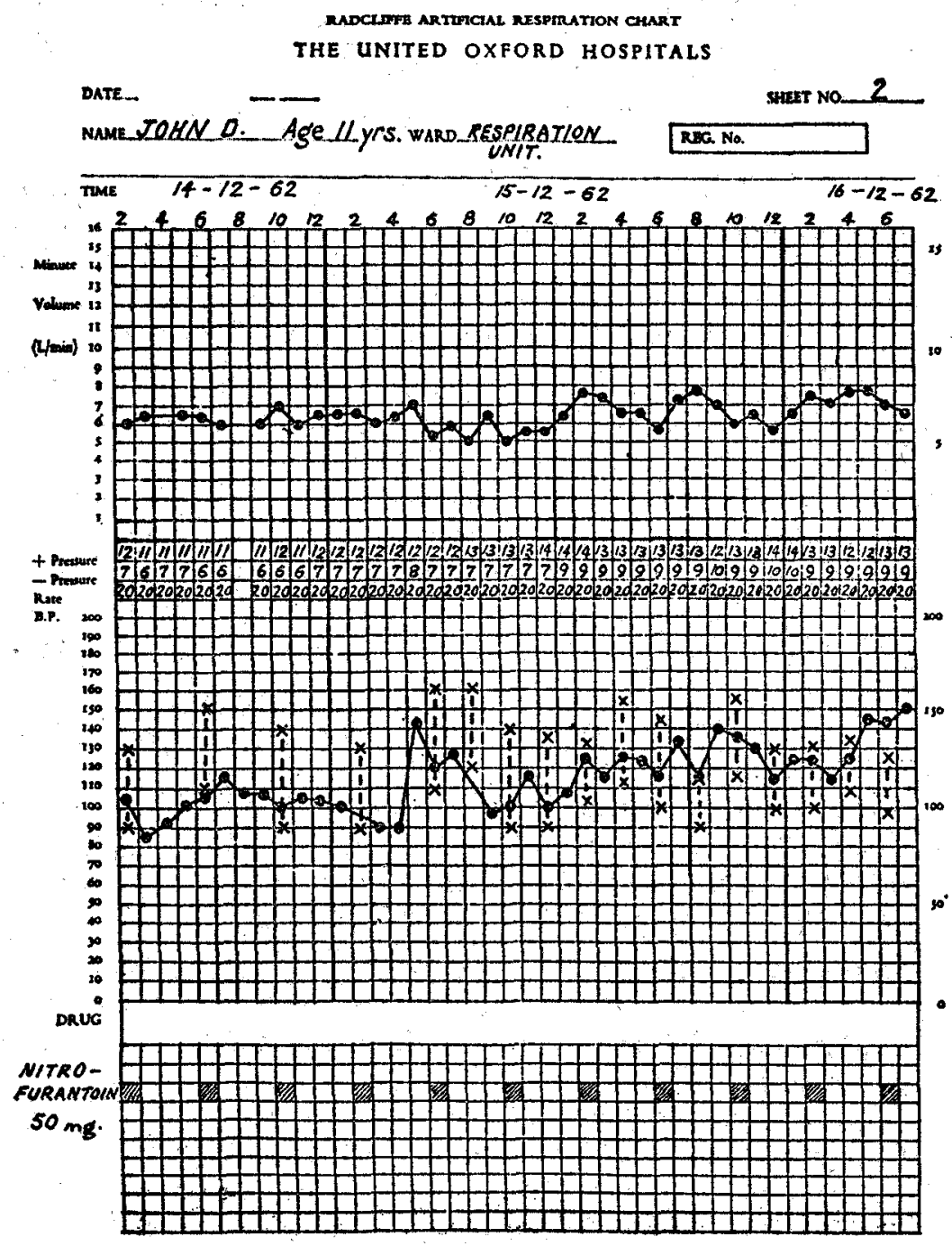

Fig. 1. The Oxford Chart. Actual size 8" ${ }^{\prime \prime}$ x $111^{\prime \prime}$.

(Reproduced by permission of Blackwell Scientific Publications Ltd.) 


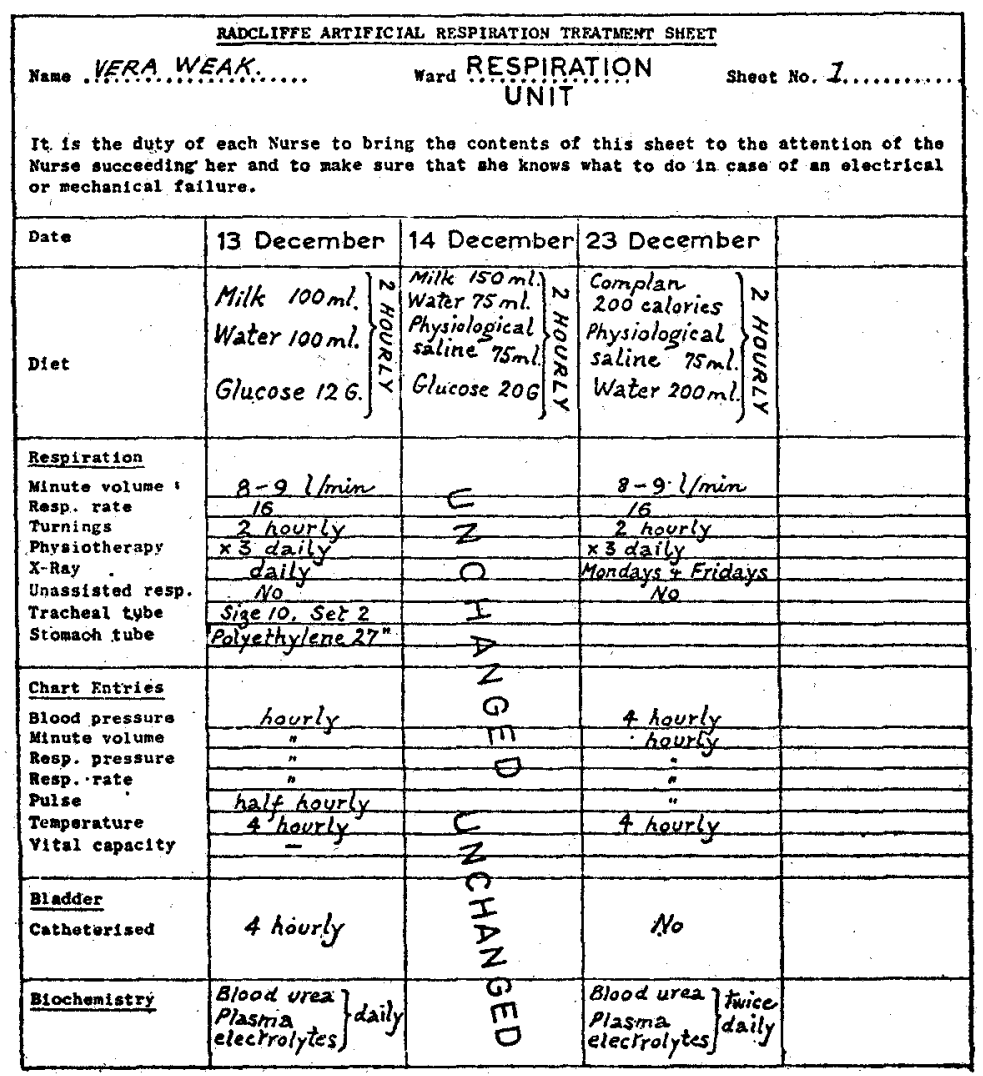

Fig. 2. The Oxford Treatment Sheet. Actual size $8^{\prime \prime} \times 10^{\prime \prime}$. (Reproduced by permission of Blackwell Scientific Publications Ltd.)

the sheet to that of hospital case notes (Fs. Med $10 \& 11$ ). Unlike its original, which would last at least four days, it is intended to last only 24 hours.

The Artificial Ventilation Chart, illustrated in Figure 4, differs little, and only in detail from its original. The number of squares across has been reduced to 24 , one for each hour, instead of the rather arbitrary 38 of the Oxford Chart. An indication has been given that the lower parts of the blood pressure section may be used for recording pulse rate and carbon dioxide tension. Spaces have been left between the sections as visual aids. 


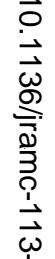

(As each procedure is carried out, place a tick in the appropriate time column.)

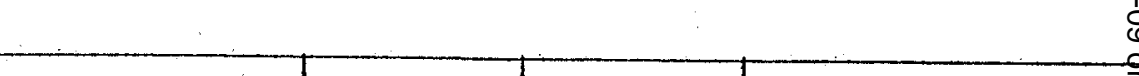

\begin{tabular}{l}
6 \\
\hline
\end{tabular}

\begin{tabular}{|c|c|c|}
\hline Procedure & $\begin{array}{c}\text { Standard } \\
\text { Instruction }\end{array}$ & $\begin{array}{c}\text { Hodification } \\
\text { of } \\
\text { Standard } \\
\text { Instruction }\end{array}$ \\
\hline $\begin{array}{l}\text { Aspirate trachea } \\
\text { and bronchi }\end{array}$ & $\begin{array}{c}\text { As } \\
\text { necessary }\end{array}$ & \\
\hline $\begin{array}{l}\text { Release cuff for } \\
2 \text { minutes }\end{array}$ & $\begin{array}{c}2 \text { hourly! } \\
\text { Aspirate } \\
\text { pharynx } \\
\text { first. }\end{array}$ & \\
\hline $\begin{array}{l}\text { Turn and treat } \\
\text { pressure areas }\end{array}$ & $\begin{array}{l}2 \text { hourly. } \\
\text { Percuss } \\
\text { chest and } \\
\text { aspirate } \\
\text { trachea } \\
\text { before and } \\
\text { after. }\end{array}$ & \\
\hline $\begin{array}{l}\text { Phy siotherapist } \\
\text { to chest \& limbs }\end{array}$ & 5 hourly & \\
\hline \begin{tabular}{|l} 
Oral toilet \\
Eyes
\end{tabular} & p.r.n. & \\
\hline Release catheter & 4 hourly & $N / A$ \\
\hline $\begin{array}{c}\text { Aspirate gastric } \\
\text { tube }\end{array}$ & & $N / A$ \\
\hline Temperature & Jenrly & 4-Hourty \\
\hline$\frac{B . P \cdot}{P .90}$ & Hourly & $4-10$ \\
\hline Pulse & Hourly & \\
\hline Respiratory rate & $\begin{array}{l}\text { Hourly. } \\
\text { Maintain at } \\
20 \text {./min. }\end{array}$ & \\
\hline $\begin{array}{l}\text { Ventilator } \\
\text { pressure } \\
\end{array}$ & Hourly & \\
\hline $\begin{array}{l}\text { Respiratory } \\
\text { minute volume }\end{array}$ & $\begin{array}{l}\text { Hourle } \\
\text { Maintain } \\
.8 . \mathrm{g} / \mathrm{min}\end{array}$ & $\begin{array}{l}10 \mathrm{~L} / \min \\
\text { from } 1\end{array}$ \\
\hline 06 & & \\
\hline
\end{tabular}
꿍

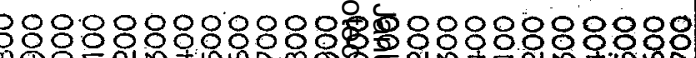
0

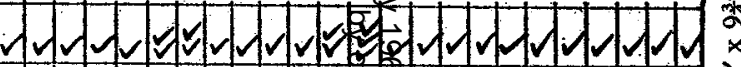
10 舟

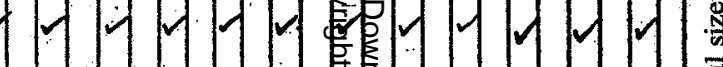




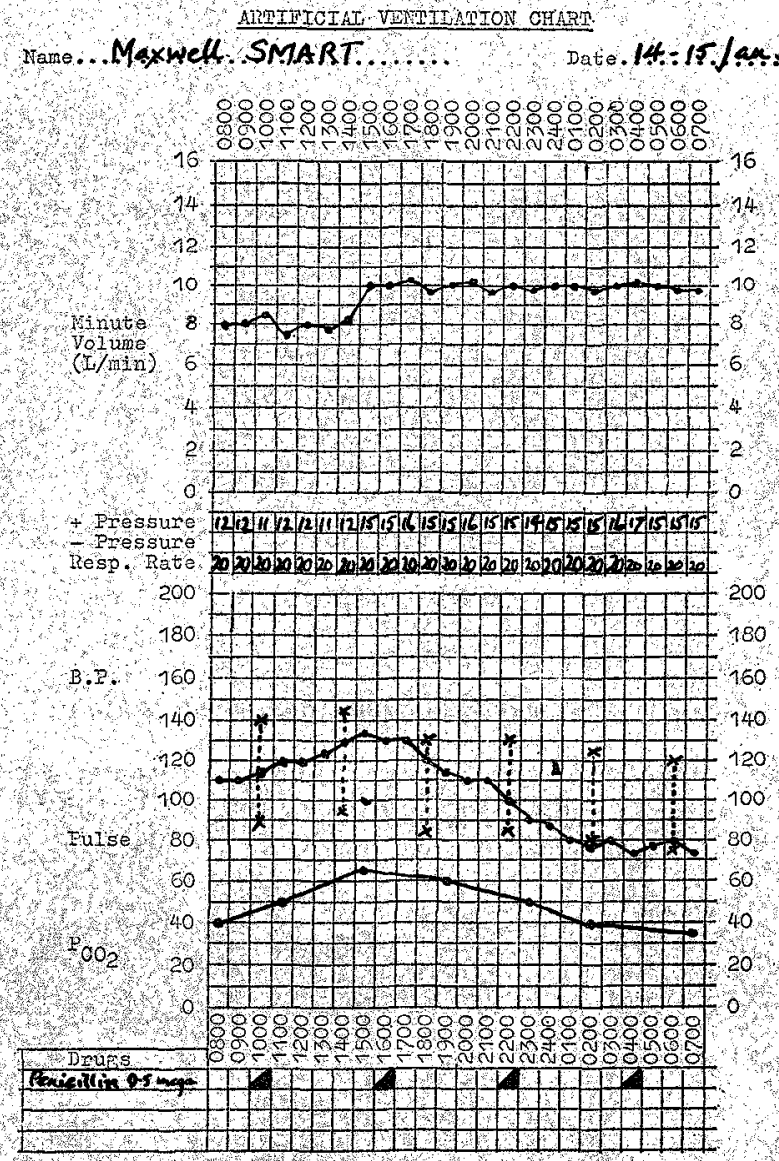

Fig, 4. The modified Chart. Actual size $71^{\prime \prime} \times 97^{\prime \prime}$.

These documents are presented in the hope that they may be helpful to other Army anaesthetists. It is appreciated that their layout and appearance are not ideal, due to the deliberate limitation of size, together with the fact that they have of necessity been typewritten.

\section{REFERENCE}

Spalding, J. M. K. and Crampton Smith, A. (1963). Clinical Practice and Physiology of Artificial Respiration. Oxford. Blackwell, 